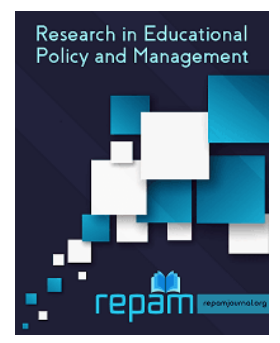

Research in Educational Policy and Management

Open Access Journal

repamjournal.org

2019, 1(1): 1-16

Research Paper

\title{
School, ethnicity and nation-building in post-colonial Myanmar
}

\author{
Francesco Bigagli*
}

\begin{abstract}
* PhD, Independent Researcher, Italy (Former Assistant Professor, Dhofar University, School of Applied Sciences and Languages, Salalah, Oman).
\end{abstract}

E-mail: frabigagli@gmail.com

\section{Article Info}

Received: 18.11.2019

Revised: 28.11.2019

Accepted: 02.12.2019

\section{How to cite}

Bigagli, F. (2019). School, ethnicity and nation-building in postcolonial Myanmar. Research in Educational Policy and Management, 1(1), 1-16.

\begin{abstract}
Drawing on concepts of ethnicity and ethnic nationalism, this paper analyzes the reasons and extent to which school education has been utilized to define postcolonial Myanmar. It will examine the way in which the nation has been defined by the suppression of the 'Other' as opposed to being formed in its integral nations. This will be done through an analysis of Myanmar's political history and, subsequently, through an examination of specific educational policies and practices such as the introduction of a one-language policy, standardized curricula and textbooks and teacher-centered pedagogies that have deliberately been used in the attempt to assimilate rather than integrate the country's ethnic diversity. The second part of the paper will look into the nature and dynamics of the country's enduring identity-based conflicts by analyzing the effects of such exclusive state building policies. It will argue that the 'ethnicization' of the education system (in favor of the Bamar majority) has both catalyzed political violence and has reinforced ethnolinguistic identities through the use of education as a tool of resistance. KEYWORDS

Educational policy; school; nation-building; ethnicity; nationalism; Myanmar.
\end{abstract}

\section{INTRODUCTION}

Listed as a lower-middle income country (World Bank, 2019a), Myanmar has been rife with violence between Bamar-majority governments and ethnic minority groups demanding greater political and human rights since the end of the British colonial period in 1948. The International Labor Organization (ILO, 2019) estimates a population of over 53 million, 68\% of which is accounted as Bamar/Burman (World Population Review, 2019). Most of its non-majority population inhabits the rural states on the borders with Bangladesh and India to the west, Laos 
and Thailand to the east and China to the northeast. While over $65 \%$ of the population aged 15 and older is stated to be in employment (ILO, 2019), one in four people in 2017 was estimated to live in poverty corresponding to almost 11.8 million people (World Bank, 2019b).

Starting 2011 with the quasi-civilian Government of President Thein Sein, economic sanctions imposed since 1997 to isolate the military regime had gradually been removed. Despite initial optimism, the country's economic growth has slowed down from $6.7 \%$ in the 2017/18 period to a $6.2 \%$ in 2018/19 (World Bank, 2019a). Apart from much needed infrastructure development and reforms, Myanmar's economic growth and poverty reduction largely depends on its political stability, particularly in relation to the ongoing peace process. Despite the ratification of a number of ceasefire agreements (Reuters, 2015), the conflict environment has not changed much since 1948 and the Government is still unable to control the majority of its borderlands and heavy combat is ongoing (Davis, 2019, July 2).

In her opening speech at the inauguration of the National Reconciliation and Peace Centre on January 1, 2017, Myanmar's State Counselor Daw Aung San Suu Kyi, leader of the first democratically elected government in November 2015, urged all representatives "to help mark 2017 as the year of peace" (Myanmar Times, 2017, January 3). Further steps towards the realization of a "peaceful democratic federal Union" based on the ratification of 2015 Nation Ceasefire Agreement (NCA) between the then Thein Sein's Government and eight ethnic armed groups were undertaken at the second and third meetings of the Union Peace Conference Panglong in May 2017 and July 2018. The signings of the NCA by the New Mon State Party and the Lahu Democratic Union in February 2018 (AP News, 2018, February 13) was seen as a further step forward to a comprehensive cease fire although some of the most powerful ethnic armed organizations (EAGs) like the Kachin and the Shan are yet to lay down their weapons. While the outcome of the Panglong's talks bodes well for the next meeting to be held early in 2020 with several agreed points on the extension of legislative, judicial, and executive powers to ethnic minority states, the highly sought-after deal on the issue of self-determination has yet to materialize (Myanmar Times , 2017, May 29). This is a serious constraint to the implementation of the NCA which advocates the right to self-determination "on the basis of liberty, equality, and justice while upholding the principles of non-disintegration of the union" (NCA, 2013, p. 1).

In the context of Myanmar, the concept of self-determination should be articulated in a way that both majority and minorities "feel they equally co-own the country" (Kapi, 2014). In practice, each member state of the Union should be able to elect its own political leaders, make decisions on how wealth is distributed, and exercise the right to mother-tongue based education. As Ignatieff (1995, p. 3) argues, "self-determination comes down to either democratic self-rule or the exercise of cultural autonomy". In this regard, consensus on education policies that would grant the right to determine instruction in a medium other than Burmese - a legacy of fifty years of military regimes -, and create/revise curricula in line with local needs will not be easy to achieve for Suu Kyi without antagonizing the Tatmadaw (i.e., 
Myanmar Armed Forces) who enjoy autonomy in their affairs under the 2008 Constitution (chapter VII).

Bearing in mind the emergency situation in a number of borderlands, "there tends to be a concern ... that the promotion of minority languages and ethnic identities will lead to greater divisiveness" (Lall \& South, 2016b, pp. 132-133) rather than unity; always with the risk of a call for secession from ethnic armed groups (Mail Online, 2017, May 28). Bush and Saltarelli (2000, p. 18) contend that there is no empirical evidence that "minority language teaching necessarily diminishes a sense of political unity". Yet in a country riven by decades of identitybased conflicts and divided along ethnic lines, the promotion of inclusive education policies through decentralization would require greater political commitment from the Government, including the Tatmadaw. This might also necessitate ethnic armed groups to discontinue using education "as a political tool to shape identities" (South \& Lall, 2016a, p. 133).

Myanmar's turbulent political history teaches us that the imposition of a specific national culture, the Bamar, as the "Socialist Way" to build and maintain national unity has simply led the country to a perpetual state of conflict and "insurgency as a way of life" (Smith, 2007, p. 15) resulting into a "nation-destroying" process (Walker, 1972). Since independence from British rule in 1948 and, more pronouncedly, after the military coup in 1962, Myanmar has essentially embarked on a mono-ethnic project of state nation-building, mainly through the predominance of the Bamar language and culture. Although the adoption of a dominant (state) language in colonial/post-colonial contexts is often legitimized as being an essential nation-building (and nation-maintenance) tool in order to encourage social cohesion, promote a sense of belonging and integration of diverse groups in all aspects of public life (Ulasiuk, Hadirka \& Romans, 2018), the way this is carried out is also crucial. While the integration of diverse groups in society is unlikely to occur without an understanding of the state language, the exclusion of minority languages and cultures can be perceived as a threat to the survival of a particular group's ethnic identity (Bush \& Saltarelli, 2000), leading to the emergence of highly resilient "minority nationbuilding" stances (Kymlicka, 2001, p. 233) working against the exclusive state policies and fuelling dissent and enduring tensions.

\section{Purpose of the Study}

Drawing on concepts of ethnicity and ethnic nationalism, this paper will first review the politics of educational reforms in post-colonial Myanmar by analyzing the extent to which school education has been used as a political tool in the state formation process by the suppression of the 'Other' as opposed to being formed in its integral nations. This will be done through an analysis of Myanmar's political history and, subsequently, through an examination of specific educational policies and practices such as the introduction of a one-language policy, standardized curricula, textbooks and teacher-centered pedagogies.

The second part of the paper will look into the nature and dynamics of the country's enduring identity-based conflicts by analyzing the effects of such exclusive state building 
policies. It will argue that the 'ethnicization' (Bush \& Saltarelli) of the education system - in favor of the Bamar majority-has both catalyzed political violence (exacerbating civil-military tensions) and has reinforced ethno-linguistic identities through the use of education as a tool of resistance. This latter point has critical implications for social cohesion, tolerance for diversity and the overall future of the country.

The conclusive part of the paper will explore ways forward to foster national unity through the promotion of inclusive education policies vis-à-vis the ongoing peace process. As Guibernau (2007, p. 27) warns us, "failure in this respect inevitably threatens social cohesion and fuels further claims for devolution and secession."

\section{Ethnicity and Nation-Building}

As research shows (Lall, 2009), inter-ethnic violence in Burma precedes sovereignty from British colonial rule. Independence hero, Gen. Aung San, was gunned down in July 1947 by a group of paramilitary. A few months earlier, at the first Panglong conference, Aung San and ethnic representatives of the Chin, Shan and Kachin Frontier Areas had unanimously agreed to the formation of a unified Burma with autonomy to be granted to the country's ethnic minority areas thus de facto paving the way for an independent federal state. Unity in diversity was Aung San's motto to "heal ethnic differences and build the new nation" (Smith, p. 38). The agreement, however, included the right to secede after ten years of independence. According to Lall (2009, p. 4), "the British colonial legacy of divide and rule entrenched differences between the Bamar majority and other minority ethnic groups [that] have challenged the state since its inception, some asking for greater autonomy and some for outright independence". The spirit of the agreement essentially envisaged the "coming together" of people possessing well-defined ethno-cultural identities which had been purposely cultivated during the colonial period, and which could represent a fertile ground for ethnic discord unless readily tackled.

One could legitimately argue that the identities of the Kachins, Chins, and others were so deeply rooted in their ethnic cultural attributes and "frontier" territories to constitute themselves distinct "nations." As Guibernau (2007, p. 47) contends, a nation can be defined as "a human group conscious of forming a community, sharing a common culture, attached to a clearly demarcated territory, having a common past and a common project for the future and claiming the right to rule itself". At its inception, the Union was a state without a sense of nation. It was fundamentally comprised of different "nations" each intrinsically defined by ethnocultural characteristics, and it is worth noting that although the vast majority of the population in Burma practises Buddhism this did not act as a potential deterrent to inter-ethnic violence. In principle, however, diversity should not preclude to a successful nation-building process. Nor should "such diversity increase the risk of warfare" (Smith, 2007, p. 21). What did, in the context of Burma, was the nationalistic approach by which the Governments of $U \mathrm{Nu}$ and, more pronouncedly, the military juntas of Gen. Ne Win and, after him, Saw Maung and Than Shwe, had come to impose the dominance of the Bamar group over others (Smith, 2007). 


\section{The Politics of Exclusion: Education as a Tool of Dispossession}

Following the assassination of Aung San, the Panglong agreement was never honored and, despite winning independence in 1948, the country has ever since plunged in a "conflict trap" (Smith, 2007). Powerful ethnic communist separatist forces which had gradually come to enjoy the support of foreign agents -most prominently Mao's China- gradually escalated into a militarization of the Union leading to General Ne Win's 1962 military coup. From 1962 to 2011, state power under Ne Win and ensuing military juntas imposed what had come to be perceived as a "Burmanization" of society by moving away from foreign cultures and repressing autochthonous ethnic ones. This was not only with the aim to re-establish the Burmese tradition - at the expense of the country's diverse identities -, and "reject (perhaps forget) the humiliating colonial past" (Aung Thwin, 2012, p. 250) but also, arguably, prevent the country from breaking apart (Smith, 2007, p. 38). As Ignatieff (1998, p. 3), with a tinge of dark irony, contends: "nationalism is an ethic of heroic sacrifice, justifying the use of violence in the defense of one's nations against enemies, internal or external". Nation-building in Burma took place within the terms of what Hans Kohn (1944) and other scholars (Greenfeld \& Chirot, 1994) call 'ethnic nationalism' where "it is the nationalist community that defines the individual" and not viceversa and where an "individual's deepest attachments are inherited, not chosen" (Ignatieff, 1998, pp. 4-5). In practice, for Ne Win, the safeguard of a united nation-state coincided with the suppression of the ethno-cultural "Other" and the imposition of "one ethnicity," that is, the Bamar, one language, Burmese, and one religion: Buddhism as "The Burmese Way to Socialism" (TBWS, 1962).

In this regard, education has played a crucial though "destructive" (Bush \& Saltarelli, 2000) role in the attempt to "unify" the new nation which translated into an "explicit and conscious project of forced assimilation" under Ne Win (Lall \& South, 2016b, p. 31). The use of education as a political tool for nation-building has been extensively researched. Scholars agree that national identity-formation is a carefully engineered process constructed over time by those in power (Guibernau, 2007, p. 15), and "the material taught in schools reflects the political ideology of the day" (Lall, 2009, p. 1). Some scholars argue that it is precisely through "free and compulsory" education that governments seek to produce political legitimacy and maintain the status quo (Green, 2013, pp. 94-95). Not surprisingly, in 1950, a new education policy aimed at providing free primary schooling was introduced. The scheme was complemented by the launch of a pilot project to implement compulsory primary education in Rangoon (Lwin, 2000, p. 7). In 1962, all schools were nationalized. As Cheesman (2003) contends, the control of the school system represents a powerful tool for the cultivation and inculcation of national principles and ideals. The crucial role of education in identity development is therefore one reason why it often becomes a target for political manipulation. As research shows, citizens' naturalization is a double-faced process that can lead to either integration or disintegration of society (Bush and Saltarelli, 2000). The process is integrative when it leads to building a society based on tolerance and respect for the Other. It is disintegrative when the outcome of the process results into 
jingoism and intolerance for diversity. Arguments that decades of warfare have been fueled by political reasons - the risk of a breaking up of the Union, or, in part, "greed" over the control of the resource-rich borderlands by some ethnic armed groups (EAGs), or simply sheer lust for power certainly have their raison d'etre though it should be clear that Myanmar's internal conflict does not fall under the "resource wars" category (Smith, 2010; Lall \& South, 2016a). To corroborate and advance Lall and South's (2016a) argument, it could be said that it was rather the attempt to eradicate diversity by replacing it with a self-same identity, as a form of neocolonialism and a way to the ethno-cultural dispossession of the "Other," that has contributed to the perpetuation of violence.

The politics of exclusion in Ne Win's Burma has been perpetuated precisely through education as a tool of dispossession of the Other's cultural identity by denying the right to mother-tongue education, the imposition of a unified curriculum and textbooks as well as a highly politicized approach of teachers.

\section{Monolingual education}

In 1962, under the 'national language policy,' Burmese was established as the national language while the use of other ethnic languages was banned. The ban included the publication of newspapers and books in languages other than Burmese (Nya Mon, 2014); reinforcing U Nu's previous 1958 policy on the use of languages. While the teaching of minority languages was still largely allowed (Nya Mon, 2014), U Nu's policy promoted Burmese as the sole medium of instruction (Lwin, 2000). This was in stark contrast with language policies employed under the British administration: Locally run Vernacular schools allowed, for example, the use of one of the "indigenous" languages.

The nexus between language and power is undeniable and, perhaps, even obvious as governments "often use language policy to serve an instrumental purpose, such as building a national identity" (Lall \& South, 2016b, p. 133). It could be argued that while the need to institutionalize the use of a specific language that everyone understands is not only crucial to effective communication but also to the sharing of a national identity (Guibernau, 2007, p. 14), failure to recognize a country's minority language(s) is tantamount to a denial of the Other's cultural identity (Bush \& Saltarelli, 2000, p. 11). Ironically, the very institutions - that is, schools - that should have exercised what Jenson (1998) calls "the practices of recognition of difference" (p. 16) have instead contributed to fostering alienation and exclusion. Not only that as learning in a "foreign" language - a concept known as "submersion" (Skutnabb-Kangas, in Benson, 2004, p. 2) - is proven to cripple a child's cognitive development. The emasculation of mother-tongue languages under Ne Win to this day has thus not only contributed to an erosion of Myanmar's ethnic cultural heritages but has fostered inequality as attested by high rates of exam failures and dropouts among minorities (Jolliffe \& Mears, 2016). 


\section{The curriculum and textbooks}

In 1962, the regime announced its education policy in line with the "Burmese Way to Socialism" by proclaiming the need to bring about a system "based on socialist moral values." Two decades on, the Head of State of Burma, Senior General Than Shwe, corroborates this line of action by emphasizing that in education "moral and discipline . . . are of prime importance . .. Only when they [children] possess good discipline, will they be able to serve the interest of the state (Lwin, 2000, p. 9). The original 1962 policy also states that "science will be given precedence in education" along with the overall target to "bring basic education within the reach of all" (TBWS, 1962, p. 23). In addition, examinations based on a pass/fail system were introduced at the end of each standard (Lwin, 2000).

The subordination of arts to science, underpinning non-critical thinking behaviors and, more to the point, a strong emphasis on civic content framing national identity-formation on the basis of a political credo tied up to ethnicity and culture (i.e., Burmese) along with continuous examinations designate the employment of what Kerr (1999) describes as the "minimal approach" to civics education. This type of approach is essentially meant to advance "exclusive and elitist interests, such as the granting of citizenship to certain groups in society but not all" (Kerr, 1999, p. 13) through politically charged texts that leave no margin to interpretation. It informs a passive behavior and a process of identity-formation subordinated to the exclusive authority of the state rather than fostering a critical approach to an understanding of citizenship values (i.e., justice, equality, tolerance for diversity).

As Apple (1992, p. 182) argues, control over the curriculum and textbooks is key "to create what a society has recognized as legitimate and truthful." History books, in particular, continue to reflect the exclusive political ideology of the military regimes. According to Nya Mon (2014), these narrate an ethnically charged vision of the world by depicting, for instance, Burman kings as heroes "for conquering the Mon kingdoms, while the Mon see them as invaders" (pp. 9-10). In general, textbooks do not contain any reference to other ethnic groups and, in some instances, present EAGs as "destructive elements and enemies" (p. 10). In so far the unification of the country, Nya Mon (2014) maintains that references to the 1947 Panglong agreement are rare also in light to the fact that it was rendered null under Ne Win.

\section{Teachers, pedagogy and quality}

Gellner (1983)'s image of teachers as "gardeners of nationalism" aptly describes their role under the military regimes. In 2006, at a primary school's ceremony, Gen. Thein Sein, the future President of the Union, addressed the audience by referring to EAGs as "saboteurs" of the nation and called onto teachers "to organize the people to clearly see the perpetration of the saboteurs and to ward it off with Union spirit" (Fink, 2001, p. 174). Teachers had no input in curriculum development and were required to teach by the book (Fink, 2001). A strong emphasis on teacher-centered pedagogy and rote-learning underpinned children's submission to authority. Teacher absenteeism, particularly in rural areas, was widespread with catastrophic 
consequences for non-majority students. In most cases, teachers deployed to work in ceasefire areas had, - and continue to have - no knowledge of the local language(s), and teaching, in most cases, was - and still is - of poor quality (Jolliffe \& Mears, 2016). Over the years, this has inevitably widened the gap in terms of access and quality of education between urban/Bamarmajority inhabited areas and rural/ethnic dominated territories. In addition, inadequate teacher training and lack of professional development as a direct consequence of major underfunding have contributed to a deterioration of the school system. According to Hayden and Martin (2013), underfunding of education was deliberate. A move, surely, to prevent people's empowerment and impose control.

There can be no doubt that the attempt to reify ethno-cultural diversity into sameness was a major factor in the perpetuation of violence. As Bush and Saltarelli $(2000$, p. 10) claim, "taken to an extreme, such repression can be termed 'ethnocide' . . . as the process whereby a culturally distinct people loses its identity as a result of policies designed to erode . . . its traditions, art forms, religious practices and cultural values." In the face of adversity, physical and cultural precariousness, ethnic communities have, however, demonstrated a strong sense of resilience in the ultimate struggle for survival and self-recognition. As we shall see, the emergence of parallel education systems (PES), run by EAGs, have not only served as an element of social resilience to re-establish normality into the lives of affected populations (Pigozzi, 1999) but have acted as a tool of resistance in an effort towards cultural re-appropriation. Interestingly, while some of these systems offer an occasion for the possibility of creating a basis for relationality and intercultural dialogue, in some other contexts, dispossession has worked to produce a narrative of socio-cultural antagonism and intolerance rendering the path towards reconciliation, mutual recognition and integration problematic.

\section{Education as a Tool of Resistance}

As noted just now, the development of PES in post-independence Myanmar can be said to represent a direct response to the policies and practices of cultural homogenization to protect autochthonous ethnic identities from extinction. Some of these PESs are worth mentioning as their conceptualization, according to Lall and South (2016a), reflects the political stance of their respective communities vis-à-vis the peace process. The Kachin state, on the border with China and India, has provided non-state education to its people for decades. In 2011, the 1994 ceasefire between the Kachin Independence Army (KIA) and the Government broke down. Interestingly, during the ceasefire period, the KIA education system was more convergent with the Government one and increasingly more divergent since the resumption of violence by switching to the Jinghpaw language and placing emphasis exclusively on Kachin culture. This, according to Lall and South (2016a), would indicate a potential call for secession in future. The Mon National Education Committee (MNEC) offers, on the other hand, somewhat of a "model" education system which bodes well for a possible integration with the Government one (Lall \& South, 2016a). A ceasefire agreement in the Mon territory has been in place for over two 
decades. Since 1994, the MNEC has been offering a curriculum similar to the Government one in Mon language at primary level, migrating to Burmese from grade 9. This particular model provides crucial advantages not only from a strictly pedagogical point of view but also from a political and socio-economic perspective (Benson, 2004). Command of Burmese and competency in the Government's curriculum signify the ability to sit the matriculation exam and progress to higher education. Fluency in the first language also represents an opportunity to fully participate in the life of the Republic. However, Nya Mon (2014) suggests that the curriculum still embraces an ethno-nationalist representation of history. In general, other PESs (e.g., Shan, Karen) provide mother-tongue based schooling and employ a distinct curriculum with little to no consideration for Burmese culture.

While the importance of PESs in the preservation of cultural heritages and resiliencebuilding process has been crucial, it could be argued that years of forced assimilation have led to a sharpening of ethno-cultural awareness among minority groups. And, growing selfawareness has come to produce discord rather than harmony, resentment - Newbury aptly calls it "resentment of the dispossessed" (Bush \& Saltarelli, 2000) in lieu of forgiveness; ultimately resulting in a fragmentation of Myanmar's society along ethno-cultural and political lines: "These divisions run deep and all the peoples have suffered" (Smith, 1994, p. 95). According to Walker (1972), in these contexts, not only minority groups become more aware of those who share their ethnic identity but are susceptible of developing an "us versus them" weltanschauung. In a darkly ironic turn of events, "ethnic mobilizers" (Walker, 1972) have used and fed into the human dimension of the conflict by imposing a prejudiced view of the world through the employment of curricula that promote a biased understanding of history and culture (Jolliffe \& Smears, 2016). Nya Mon (2014, p. 10) argues that history textbooks in use in Karenni and Shan schools present Burmans as "oppressors while their ethnic groups were oppressed or innocent". Significantly, Lall and South (2011, p. 139) point out that Karenni children "are being educated to become (virtual) citizens of a putative Karen free state, rather than the Union of Myanmar". Unsurprisingly, a trend towards xenophobia has become more virulent and has gone mainstream in the Arakan state on the border with Bangladesh. Muslim Rohingyas are targets of ethnic-cleansing type of attacks by the Arakan Army and Buddhist mobs, with the laissez-faire complicity of the Tatmadaw. As UN officials warn what is at risk is not simply the reputation of Suu Kyi in dealing with the Rohingyas' crisis as well as other minorities but the future of the Union itself (Reuters, 2017).

Education in post-independence Myanmar has had a majorly destructive role. It was and still is part of the problem since it has served "to divide and antagonize groups both intentionally and unintentionally" (Bush \& Saltarelli, 2000, p. 33). While the example of the Mon community gives hope for creating the conditions of integration through diversity, the essential question running through the next section and conclusion is how can inclusive education leading to a process of social transformation be introduced and/or sustained within transitional systems, including the state one, as well as areas still characterized by tension and violence. 


\section{Inclusive Education: A Roadmap to Nation-(Re)building and Peace?}

Promising steps towards a reform of the education system with a focus on inclusive policies and quality in line with Education for All and Millennium Development goals have been undertaken since 2014 with the introduction of a new Education Law and the 2016-2021 National Education Strategic Plan (NESP). The law includes provisions for limited decentralization and mother tongue-based schooling. Amendments to the law were made in June 2015 following clashes between the police and students (Radio Free Asia, 2015, March 10) who demanded a further reduction of centralized control congruent with increased local empowerment over the development of curricula as well as the teaching of ethnic subjects and use of ethnic languages (Jolliffe \& Mears, 2016).

While commendable, reform efforts have had "limited success so far" (Jolliffe \& Mears, 2016, p. 32). The teaching of ethnic subjects is still not compulsory and takes place outside of school hours. Textbooks are translated into local languages and there is a major lack of teachers for non-majority languages. Besides, "the law states that ethnic languages should only be used 'if necessary,' and 'alongside Myanmar,' rather than asserting that teachers should use whatever language is most conducive to learning" (Jolliffe \& Mears, 2016, p. 37). Most scholars (Benson, 2004; Buhmann \& Trudell, 2008) agree that the use of mother-tongue based schooling at primary level with the subsequent introduction of the second language as the medium of instruction, as in the case of the Mon model, is not only pedagogically sound but would help create the conditions for political and social integration. And yet, the examples of post-conflict multi-ethnic nations like Kosovo and Macedonia have proven that mother-tongue based education alone might lead to cementing the ethnic divide (UNICEF, 2009) unless complemented by peace and citizenship education programs supported by critical thinking skills within the terms of Kerr's (1999) "maximal interpretation". Unlike "narrower" civics education, citizenship programs promote an epistemological approach to the construct of national identity based on citizens' rights and responsibilities rather than subordination to a state-imposed vision of the world (Kerr, 1999); thus offering the opportunity to move away from a concept of nationalism tied up to ethnicity and mono-culturalism to one framed around Ignatieff's civic nationalism which "envisages the nation as a community of equal, rights-bearing citizens sharing the same attachment and respect to the nation's civic institutions, values and rule of law" (Ignatieff, 1995, p. 4). According to Smith (2010), citizenship education programs are particularly appropriate in conflict-ridden societies where national identity formation is linked to ethnicity.

In this regard, while it has been largely criticized for failing to include ethnic teachers, community representatives and civil society organizations in the policy-making process (Voanews, 2017, April 22), the NESP places a strong emphasis on critical thinking which is crucial, as noted, in citizenship education. However, while the NESP promotes the development of specific curricula with 'local' components, put together by each state of the Union, the new 
primary school curriculum only allocates five class periods per week for ethnic-based content (Myanmar Times, 2019, August 6; Frontier Myanmar, 2019, May 20). In addition, apart from a "life skills" module, the NESP makes no provision for the implementation of specific peace education and/or school conflict resolution skill programs, including opportunities for interethnic community projects which would help combat intolerance; ultimately contributing to a process of identity re-building and social transformation (Pigozzi, 1999). As Sinclair (2002, p. 31) states although "education alone cannot build and maintain peace," peace education programs are crucial to fostering ethnic rapproachment. Efforts in this sense are being carried out by aid organizations in cooperation with the MoE although there is no national strategy in place and there is still very little engagement of local stakeholders. Sinclair (2002) maintains that a "bottom up" participatory approach is a widely accepted best practice to produce sustainable outcomes in the least possible time. However, the implementation of (extra-) curricular activities that promote tolerance delivered within educational structures that are still fundamentally exclusive or elitist defeats the purpose (Bush \& Saltarelli, 2000). This largely explains the lack of trust on the part of ethnic communities across ceasefire areas to send their kids to newly built state schools perceived as an encroachment of political and territorial control (Jolliffe \& Mears, 2016). Lall and South (2016a) additionally argue that aid agencies, perhaps unintentionally, are seen as promoting the government agenda in broadening state structures.

Ultimately, the most persuasive argument to achieve national reconciliation and contribute to the establishment of "a genuine, federal democratic union" (Suu Kyi, 2016) is the one put forward by Jolliffe and Mears (2016) arguing for a recognition of the PESs. This would promote trust and "demonstrate that ceasefires will not be used to undermine existing systems" (Jolliffe \& Mears, 2016, p. 51).

\section{Conclusion}

The road towards peace is a process and must be one based on mutual recognition and tolerance through education as a tool of integration. The case of the Mon community shows that the ethnic divide is rarely total despite past violence as attested by the implementation of bilingual policies and practices promoting Mon schools as spaces of relationality and understanding of diversity. The recognition of the Mon educational system would certainly represent a way forward towards sustainability although this would be perceived by the Government, including the powerful Tatmadaw, as an acknowledgment of the right to selfdetermination. Arguably, failure in (re-)integrating existing structures could, in the long run, always provide room for further divisions and/or leverage for EAGs to continue using "education as a political tool." This would not only affect areas still torn by violence but transitional systems too. As Baumann (2009, p. 112) argues, as long as "negative, endogenous structures are left over as virulent factors, the danger of society's return to violence is eminent. Thus, the peace process remains fragile". And yet, until the Government and EAGs persist to lead the peace process as a top-down affair without the inclusion of civil society groups, education issues will 
continue to hang on the margins of politics (Lall \& South, 2016a). This is precisely why, wherever possible from a security perspective, aid organizations in cooperation with $\mathrm{MoE}$, as provided in the NCA (2013), should provide support to both state and EAG-run schools aiming at a convergence of efforts to "disarm" history and culture (Bush \& Saltarelli, 2000) along with bottom-up community-based activities focused on peace-building and citizenship education programs. Efforts to look for opportunities to mitigate divisions and advocate sensitivity towards the Other should never stop. Considering the complexities of Myanmar's peace process, education can certainly not wait.

\section{REFERENCES}

AP News. (2018, February 13). 2 groups join Myanmar government's peace process. Retrieved from https://apnews.com/e668736f3c4b44cfa310addefd4da1e3

Apple, M. W. (1992). The text and cultural politics. Educational Researcher, 21(7), 4-19.

Aung-Thwin, M., \& Aung-Thwin, M. (2012). A history of Myanmar since ancient times: Traditions and transformations. London: Reaktion Books.

Baumann, M. (2009). Understanding the Other's "understanding" of violence. International Journal of Conflict and Violence, 3(1) 107-123.

Benson, C. (2004). The importance of mother tongue-based schooling for educational quality. Paris: UNESCO.

Buhmann, D. \& Trudell, B. (2008). Mother tongue matters: Local language as a key to effective learning. Paris: UNESCO. Retrieved November 25, 2019, from http://unesdoc.unesco.org/images/0016/001611/161121e.pdf

Burma Library. (2008). Constitution of the Republic of the Union of Myanmar. Ministry of Information. Retrieved November 15, 2019, from http://www.burmalibrary.org/docs5/Myanmar_Constitution-2008-en.pdf

Bush, K. D. \& Saltarelli, D. (2000). The two faces of education in ethnic conflict: Towards a peacebuilding education for children. Florence, Italy: UNICEF, United Nations Children's Fund, Innocenti Research Centre.

Cheesman, N. (2003). School, state and Sangha in Burma. Comparative Education, 39(1), 45-63. Davies, A. (2019, July 2). Why Myanmar is losing the Rakhine war. Retrieved November 25, 2019, from https://www.asiatimes.com/2019/07/article/why-myanmar-is-losing-the-rakhinewar/

Frontier Myanmar. (2019, May 20). Mon lead the way in mother tongue education. Retrieved December 2, 2019, from https://frontiermyanmar.net/en/mon-lead-the-way-in-mothertongue-education

Gellner, E. (1983). Nations and nationalism. Ithaca: Cornell University Press.

Green, A. (2013). Education and state formation. London: Palgrave Macmillan. 
Greenfield, L., \& Chirot, D. (1994). Nationalism and aggression. Theory and Society, 23(1), 79103.

Guibernau, M. (2007). The identity of nations. Cambridge: Polity.

Hayden, M., \& Martin, R. (2013). Recovery of the education system in Myanmar. Journal of International and Comparative Education, 2(2), 47-57.

Ignatieff, M. (1995). Blood and belonging: Journeys into the new nationalism. London: BBC Books.

International Labor Organization (ILO). (2019). Myanmar: employment and environmental sustainability fact sheets 2019. Retrieved November 25, 2019, from https://www.ilo.org/wcmsp5/groups/public/---asia/---ro-bangkok/---ilo yangon/documents/publication/wcms_624758.pdf

James, H. (2004). Governance and civil society in Myanmar: Education, health, and environment. London: Routledge.

Jenson, J. (2002). Identifying the links: Social cohesion and culture. Canadian Journal of Communication, 27. Retrieved November 18, 2019, from http://www.cjconline.ca/index.php/journal/article/viewFile/1289/1310

Jenson, J. (1998). Mapping social cohesion. CPRN Study, 6(3). Retrieved October 11, 2019, from http://rcrpp.ca/documents/15723_en.pdf

Jolliffe, K., \& Speers Mears, E. (2016). Strength in diversity: Towards universal education in Myanmar's ethnic areas. The Asia Foundation. Retrieved November 25, 2019, from http://asiafoundation.org/wp-content/uploads/2016/10/Strength-in-Diversity-TowardUniversal-Education-Myanmar-Ethnic-Area.pdf

Jolliffe, K. (2015). Ethnic conflict and social services in Myanmar's contested regions. The Asia Foundation. Retrieved November 18, 2019, from https://asiafoundation.org/resources/pdfs/MMEthnicConflictandSocialServices.pdf

Kapi, S. (2014). Self-determination and constitutional reform in Burma. The Salween Institute for Public Policy. Retrieved November 17, 2019, from http://www.salweeninstitute.org/home---self-determination-and-constitutional-reformin-burma.html

Kerr, D. (1999). Citizenship education in the curriculum: An International review. Journal of Curriculum Studies. Retrieved December 2, 2019, from http://citeseerx.ist.psu.edu/viewdoc/download?doi=10.1.1.585.2377\&rep=rep1\&type=pdf Kymlicka, W. (2001). Politics in the vernacular: Nationalism, multiculturalism, and citizenship. Oxford Scholarship Online. DOI: 10.1093/0199240981.001.0001

Kohn, H. (1944). The Idea of nationalism: A study in its origins and background. New York: Macmillan.

Lall, M. \& South, A. (2013). Comparing models of non-state ethnic education in Myanmar: the Mon and Karen national education regimes. Journal of Contemporary Asia, 44. 
Lall, M. \& South, A. (2016a). Language, education and the peace process in Myanmar. Contemporary Southeast Asia, 38(1), 128-53.

Lall, M. \& South, A. (2016b). Schooling and conflict: Ethnic education and mother-tongue based teaching in Myanmar. The Asia Foundation. Retrieved November 15, 2019, from http://asiafoundation.org/resources/pdfs/SchoolingConflictENG.pdf

Lall, M. (2009). Ethnic conflict and the 2010 elections in Burma. Asia Program Paper, 4.

London: Chatham House.

Lall, M., \& Vickers, E. (Eds.). (2009). Education as a political tool in Asia. London: Routledge.

Lwin, T. (2010). Critical thinking: The Burmese traditional culture of education. Retrieved November 11, 2019, from http://www.thinkingclassroom.org/uploads/4/3/9/0/43900311/lwin_t._2010._critical_th inking_the_burmese_traditional_culture_of_education.pdf

Lwin, T. (2000). Education in Burma: 1945-2000. Retrieved November 11, 2019, from https://www.thinkingclassroom.org/uploads/4/3/9/0/43900311/1._Iwin_t._2000_edu cation_in_burma_1945-2000_2000_english_.pdf

Lwin, T. (2002). Issues surrounding curriculum development in the ethnic nationality areas of Burma. Retrieved November 11, 2019, from http://www.thinkingclassroom.org/uploads/4/3/9/0/43900311/4._issues_surrounding_c urriculum_development_in_the_ethnic_minority_areas_of_burma,_2002.pdf

Mail Online. (2017, May 28). Secession fears cloud Myanmar peace talks. Retrieved November 11, 2019, from http://www.dailymail.co.uk/wires/afp/article-4549516/Secession-fearscloud- Myanmar-peace-talks-government.html

Myanmar Times. (2019, August 6). New basic school curriculum 'a hit with students, parents'.

Retrieved December 2, 2019, from https://www.mmtimes.com/news/new-basic-schoolcurriculum-hit-students-parents.html

Myanmar Times. (2017, January 3). State Counselor opens peace centre. Retrieved November 11, 2019, from http://www.mmtimes.com/index.php/national-news/nay-pyi-taw/24391state-counsellor-opens-peace-centre.html

Myanmar Times. (2017, May 29). Secession, self-determination haunt second round of $\begin{array}{llll}\text { Panglong } \quad \text { Conference. } & \text { Retrieved } & \text { November }\end{array}$ http://www.mmtimes.com/index.php/national-news/26168-secession-self determination-haunt-second-round-of-panglong-conference.html

Myanmar Times. (2017, May 3). Fighting between Tatmadaw and TNLA forces reported in Namkham. Retrieved November 11, 2019, from http://www.mmtimes.com/index.php/national-news/25823-fighting-between-tatmadaw and-tnla-forces-reported-in-namkham.html

Myanmar Times. (2017, May 30). Govt, ethnic groups sign 33 agreements at the end of second 
Panglong. Retrieved November 11, 2019, from http://www.mmtimes.com/index.php/nationalnews/26184-govt-ethnic-groups-sign-33-agreements-at-the-end-of-second-

panglong.html

NESP. (2016). The National education strategic plan 2016-2021. Retrieved December 2, 2019, from http://www.moe.gov.mm/en/?q=content/national-education-strategic-plan

NCA. (2013). The nationwide ceasefire agreement between the Government of the Republic of the Union of Myanmar and the ethnic armed organizations. Retrieved November 11, 2019, from http://www.mmpeacemonitor.org/research/ceasefiredocument

Nya Mon, P. (2014). Education reform and national reconciliation in Burma. Retrieved November 25 , 2019, from https://www.salweeninstitute.org/uploads/1/2/6/3/12630752/ed_reform_and_national _reconciliation_1.pdf

Ulasiuk, I., Hadirca, L., \& Romans, W. (Eds.). (2018). Language policy and conflict prevention. Leiden \& Boston: Brill Nijhoff.

Union of Burma. (1956). Resolution on the octennial report on the state of education in Burma for the years 1947-1948 to 1954-1955. Ministry of Education. Retrieved November 17, 2019, from http://www.khamkoo.com/uploads/9/0/0/4/9004485/octennial_report_on_education_i n_burma_1947-1955.pdf

Özkırımli, U. (1999). Theories of nationalism: A critical introduction. New York: St. Martin's Press. Pigozzi, M. J. (1999). Education in emergencies and for reconstruction: A developmental approach. UNICEF. Retrieved December 2, 2019, from https://bettercarenetwork.org/sites/default/files/attachments/Education\%20in\%20Eme rgencies\%20and\%20for\%20Reconstruction.pdf

Radio Free Asia. (2015, March 10). Myanmar police beat education law protesters. Retrieved November 11, 2019, from http://www.rfa.org/english/news/myanmar/police03102015164654.html

Reuters. (2015, October 15). Myanmar signs ceasefire with eight armed groups. Retrieved November 11, 2019, from http://www.reuters.com/article/us-myanmar-politicsidUSKCNOS82MR20151015

Reuters. (2016, November 30). U.N. warns Myanmar government reputation at stake over Rohingya crisis. Retrieved November 11, 2019, from http://www.reuters.com/article/usmyanmar-rohingya-un-idUSKBN13O2VW

Suu Kyi, A. S. (2016, April 18). Address to the Union. Retrieved November 11, 2019, http://www.reuters.com/article/us-myanmar-politics-idUSKCNOXFOU6

Sercombe, P. \& Ruanni, T., et al. (2014). Language, education and nation-building: Assimilation and shift in Southeast Asia. New York: Palgrave Macmillan.

Sinclair, M. (2002). Planning in and after emergencies. Paris: UNESCO, IIEP. 
Smith, A. (2010). The influence of education on conflict and peacebuilding. Paris: UNESCO. Retrieved November 11, 2019, from http://unesdoc.unesco.org/images/0019/001913/191341e.pdf

Smith, M. (1994). Ethnic groups in Burma: Development, democracy and human rights. London: Antislavery International.

Smith, M. (2007). State of strife: The dynamics of ethnic conflict in Burma. East West Centre, Washington: Policy Studies.

The Burmese Way to Socialism (TBWS) (1962). Retrieved November 11, 2019, from http://www.ibiblio.org/obl/docs/The_Burmese_Way_to_Socialism.htm

UNESCO. (2005). First language first: Community-based literacy programs for minority language contexts in Asia. Retrieved June 3, 2017, from http://unesdoc.unesco.org/images/0014/001402/140280e.pdf

UNESCO. (2011). The hidden crisis: Armed conflict and education, EFA global monitoring report. Paris: UNESCO.

UNICEF. (2009). Multiculturalism and Interethnic Relations in Education. Retrieved November 11, 2019, from http://www.unicef.org/tfyrmacedonia/Study_ENGsm(1).pdf

Voanews. (2017, April 22). Myanmar has new education plan, but not all are happy. Retrieved November 11, 2019, from https://learningenglish.voanews.com/a/myanmar-has-neweducation-plan-but-not-all-are-happy/3818472.html

Walker, C. (1972). Nation-building or nation-destroying. World Politics, 24(3), pp. 319-355.

Washington Diplomat. (2017, March 30). World turns blind eye to Yemen's civil war, Rohingya refugees and South Sudan's famine. Retrieved November 11, 2019, from http://www.washdiplomat.com/index.php?option=com_content\&view=article\&id=1515 9:world-turns-blind-eye-to-yemens-civil-war-rohingya-refugees-and-south-sudansfamine $\&$ catid $=1556$ : april-2017\& Itemid $=428$

World Bank. (2019a, April). The World Bank in Myanmar. Retrieved November 11, 2019, from https://www.worldbank.org/en/country/myanmar/overview\#1

World Bank. (2019b). Myanmar living conditions survey 2017. Retrieved November 24, 2019, from

http://documents.worldbank.org/curated/en/921021561058201854/pdf/MyanmarLiving-Condition-Survey-2017-Report-3-Poverty-Report.pdf

World Population Review. (2019). Myanmar population 2019. Retrieved November 25, 2019, from http://worldpopulationreview.com/countries/myanmar-population/ 